\title{
Possibilities of Using Semi-Transparent Photovoltaic Modules on Rooftops of Greenhouses for Covering Their Energy Needs
}

\author{
John Vourdoubas \\ Department of Natural resources and environmental engineering, Technological Educational \\ Institute of Crete, 3 Romanou str., 73133, Chania, Crete, Greece.
}

Tel: +30-28210-23070, Fax: +30-28210-23003.

Received: November 15, 2015 Accepted: November 22, 2015 Published: December 9, 2015

doi:10.5296/jas.v4i1.8694 URL: http://dx.doi.org/10.5296/jas.v4i1.8694

\begin{abstract}
Semi-transparent photovoltaic cells allow the transmittance of solar irradiance through them and they have been used in building's skylights and facades. Their use on rooftops of greenhouses can result in electricity generation which can cover part or all of their energy needs without affecting the growth of the plants. This also results in the decrease of cooling requirements during the summer since less solar irradiance is entering the greenhouse and lower $\mathrm{CO}_{2}$ emissions due to energy use in it. However, their current prices are high compared with the prices of opaque PV cells. The purpose of the present work is to investigate the possible use of semi-transparent PV modules placed on the roof of energy intensive greenhouses in Crete-Greece in order to cover their energy requirements and sell the surplus electricity into the grid. Two different cases have been studied where greenhouses of 1,000 $\mathrm{m}^{2}$ each cover their high heating needs using heat pumps and solid biomass. PV modules of 42.5 KWp can be placed on their roofs covering slightly less than $50 \%$ of their surface allowing enough solar irradiance to enter the greenhouse. In the first case the generated electricity can cover more than $80 \%$ of total energy needs and in the second all the energy needs offering the possibility of selling the surplus electricity to the grid. However, the current high prices of semi-transparent PVs do not favour their use by farmers since their installation costs are high. Future financial support from the government could increase their attractiveness for commercial applications in greenhouses.
\end{abstract}

Keywords: Semi-transparent photovoltaics, energy, electricity generation, greenhouses, cost, environmental impacts 


\section{Introduction}

Greenhouses need energy to cover their requirements for heating, cooling, lighting and operation of various electric devices. In Mediterranean region, greenhouse construction is rather simple using light materials compared to central and northern Europe and their energy requirements are relatively low. The majority of greenhouses use conventional energy sources in order to cover their energy needs like heating oil, gas and electricity and the use of renewable energy sources in them is rather limited. However, the necessity to mitigate climate changes results in higher use of renewable energies in various sectors, including greenhouses. The possibility of using agricultural greenhouses in order to grow various crops and at the same time to generate energy, increasing farmer's income has attracted little attention until now. However, the advances of renewable energy technologies make it possible since greenhouses can generate useful energy not only for covering their own needs, but also for selling the surplus into the grid. This reduces the greenhouse gases emitted due to fossil fuels use in them. The effect of installing opaque PV cells on the roofs of greenhouses has been studied (Castellano, 2014). He found that, if they cover 25-50\% of the horizontal greenhouse roof, the growth of the plants was not affected. A feasibility study of semi-transparent PV cells integrated on greenhouse covering has been presented (Gossu et.al., 2010 ). PV moduli were connected to the grid, they had transparency in the range of 50-75\% and they were covering south oriented roof only. Shading level was 10-19\%, nominal power was 94-188 KWp and annual electricity production was 112,800- 260,200 KWh. PV cells investment had a positive net present value and its payback time was 10-13 years. Limits and prospects of PV cells on the rooftops of Mediterranean greenhouses has been studied (Marucci et. al., 2013, Marucci et.al., 2012). They differentiated the light greenhouses with cheap coverings used in Mediterranean region with the heavier greenhouses used in central and northern Europe. They have investigated the possibility of using flexible semi-transparent photovoltaics in order to generate an additional income to the farmers and to reduce the cooling loads during the summer. An experimental evaluation and an energy modeling of a greenhouse concept have been presented (Bambara et. al., 2015). With reference to the vertical farm concept which requires less energy for heating and the same energy for cooling compared with conventional greenhouses, semi-transparent photovoltaics generate electricity and provide shading to them. A prototype semi-transparent PV cell for greenhouse roof applications has been reported (Akira et. al., 2014). Two different types of cells have been studied comparing electricity generation and greenhouse shading. The possibility of using semi-transparent photovoltaics in Mediterranean greenhouses in order to generate electricity and to shade them has been studied (Marucci et. al., 2013). The possibilities of using renewable energies in order to cover all the energy needs of greenhouses have been investigated (Vourdoubas, 2015). Two case studies have been analyzed where PV cells and solid biomass were used in the first and PV cells and geothermal heat pumps in the second. A performance analysis of greenhouses using integrated photovoltaic modulus supported by computer simulation has been presented (Carlnini et. al.,2010). A study of the use of semi-transparent PV films for Mediterranean greenhouses regarding the transmittance of the PV films in the visible range and in the infrared range has been presented (Marucci et. al., 2012 ). An assessment of a greenhouse cooling system using earth to air heat exchanger 
assisted with solar-PV cells has been made (Yildiz et. al., 2011). The Italian policy regarding photovoltaic investments in greenhouses has been presented (Tudisca et.al., 2013). Performance parameters of a heat pump used to meet the heating and the dehumidification requirements in a greenhouse has been studied (Chou et.al., 2004). Trends and perspectives for using renewable energy sources in the greenhouse industry have been discussed (Vox et. al., 2008). Use of a ground source heat pump assisted with a solar energy system for heating a greenhouse has been assessed (Ozgener et. al., 2007). Sustainable greenhouse horticulture in Europe has been analyzed and suggestions for the use of various renewable energies like low temperature geothermal energy, solid biomass, solar PV which should be supported have been made (Campiotti et. al., 2012). An assessment of using various renewable energies like geothermal energy, solar PV, solid biomass and geothermal heat pumps in greenhouses has been reported (Vourdoubas, 2015). The author concluded that solid biomass and geothermal energy are economically attractive, but solar-PV and geothermal heat pumps are not.

\section{Semi-transparent photovoltaic cells}

Semi-transparent photovoltaic cells allow solar irradiance to pass partly through them presenting some benefits in various applications compared with opaque PV cells. Although their prices are relatively high compared with opaque photovoltaic prices their use in buildings (facades, skylights, etc) is increasing. Energy and cost parameters of crystalline semi-transparent photovoltaics integrated in building's skylights have been investigated (Li et. al., 2009). Light transmittances of $20.1 \%$ and $21.5 \%$ have been found and power conversion of $10.83 \%$. Energy and cost parameters of applications of amorphous semi-transparent PV cells integrated in office buildings have been also investigated ( $\mathrm{Li}$ et. al., 2009). Solar irradiance transmittance was estimated at $11.7 \%$ and $11.4 \%$ and the daily power conversion efficiency at $6.3 \%$. Thermal and electrical performance of semi-transparent PV modules in buildings has been analyzed (Park et. al., 2010). They found that a clear day temperature of the PV modules placed on the building can reach $55^{\circ} \mathrm{C}$ which decreases the power output of the photovoltaic cells. The behavior of semi-transparent photovoltaics in residential applications has been studied (Wong et. al., 2008). They found that semi-transparent PV modules placed on buildings result in power generation, increased heating during the winter, increased indoor daylighting, but also in summer overheating due to solar irradiance transmittance. Various characteristics of semi-transparent polycrystalline modules available on the market are presented in Table 1.

Table 1. Characteristics of various semi-transparent polycrystalline modules

\begin{tabular}{|l|l|}
\hline Nominal power per module & $141-250 \mathrm{Wp}$ \\
\hline Area per module & $0.71-2.22 \mathrm{~m}^{2}$ \\
\hline Weight & $14.5-33.9 \mathrm{~kg} / \mathrm{m}^{2}$ \\
\hline Power per $\mathrm{m}^{2}$ & $85-100 \mathrm{Wp} / \mathrm{m}^{2}$ \\
\hline Efficiency & $14-18 \%$ \\
\hline Transparency & $16-37 \%$ \\
\hline Price & $1-2.7 € / \mathrm{Wp}\left[142.4-282 € / \mathrm{m}^{2}\right]$ \\
\hline
\end{tabular}


*Source: prices of various companies during 2015(BIC, ACROPOL, VIDURSOLAR, ONYX). Prices depend on size and quantity ordered.

Various characteristics of semi-transparent thin film modules available on the market are presented in Table 2 .

Table 2. Characteristics of various semi-transparent thin film modules

\begin{tabular}{|l|l|}
\hline Nominal power per module & $31.68-102 \mathrm{Wp}$ \\
\hline Area per module & $0.72-2.30 \mathrm{~m}^{2}$ \\
\hline Weight & $16.2-37.5 \mathrm{~kg} / \mathrm{m}^{2}$ \\
\hline Power per $\mathrm{m}^{2}$ & $44-63 \mathrm{Wp} / \mathrm{m}^{2}$ \\
\hline Efficiency & $7-8 \%$ \\
\hline Transparency & $10-14 \%$ \\
\hline Price & $1-4.4 € / \mathrm{Wp}\left[45-193.6 € / \mathrm{m}^{2}\right]$ \\
\hline
\end{tabular}

*Source: prices of various companies during 2015 ( BIC, ACROPOL, ONYX), Prices depend on size and quantity ordered.

\section{Use of Semi-Transparent Photovoltaic Modules in Agricultural Greenhouses}

Semi-transparent photovoltaics can be used in greenhouses in order to generate electricity for covering their energy needs including electricity, heat and cooling and selling the surplus into the grid. Since semi-transparent PV cells placed on the roof reduce the solar irradiance incoming into the greenhouse, they also reduce the cooling load particularly in Mediterranean greenhouses which have high cooling needs during the summer. For obtaining higher energy efficiencies, it is preferable to place the PV modules on the rooftops in south orientation. Since the use of the abovementioned semi-transparent PV modules on the top of greenhouses will reduce the incoming solar radiation, it is better to cover only part of their upper surface allowing enough irradiance to reach to the crop. Therefore, the use of semi-transparent photovoltaic modules for covering rooftops of greenhouses may result in many benefits including:

1. Generation of electricity in order to meet their energy needs.

2. Generation of surplus electricity which can be sold to the grid offering an additional income to the farmers. In order to do so, the legal framework for selling solar-PV electricity to the grid must exist.

3. Reduction of the cooling load during the summer since semi-transparent photovoltaics reduce the incoming solar irradiance into the greenhouse

4. Decrease or zeroing $\mathrm{CO}_{2}$ emissions from the greenhouse due to energy use in it. 
The use of semi-transparent photovoltaics is of particular interest for modern highly automated Mediterranean greenhouses (like hydroponics) growing crops which require heating and cooling, therefore consuming a lot of energy. High annual solar irradiance in Mediterranean region allows the generation of large electricity amounts from PVs which can cover the greenhouse energy requirements selling at the same time the excess electricity to the grid.

\section{Energy Needs of Greenhouses}

Agricultural greenhouses consume energy for heating, cooling, lighting, and operation of various electric devices. Energy consumption depends mainly on the type of construction, local climate and the cultivated crop. In Mediterranean region greenhouses construction is light, climate is mild compared with central and northern Europe and their energy requirements are relatively low. In general, in Mediterranean region heating requirements are low, but cooling needs are higher compared with northern countries. Most of the energy used in them is consumed for heating while only a small percentage of it for lighting and operation of electric devices including cooling devices. Renewable energy sources including solar energy, solid biomass and geothermal energy are not often used in greenhouses, which are using mainly fossil fuels including heating oil and natural gas for heat generation and grid electricity for other operations. There are currently not many commercial greenhouses using solar thermal energy, geothermal energy and solid biomass for heat generation or solar PV and wind mills for power generation, although renewable energies can cover all the energy requirements of modern greenhouses (Vourdoubas, 2015). Energy requirements of a greenhouse with flowers cultivation have been estimated at $14 \mathrm{KWh} / \mathrm{m}^{2}$ year for electricity and $220 \mathrm{KWh} / \mathrm{m}^{2}$ year for heating (Vourdoubas, 2015). Although typical light Mediterranean greenhouses used for vegetables production do not require a lot of energy, there are other types of greenhouses like hydroponics or those used for flowers cultivation which consume a lot of energy. Usually maintenance of indoor temperatures at desired levels with proper heating and cooling increases crops productivity, but also increases energy requirements and energy cost in them.

\section{Use of semi-transparent photovoltaic cells in greenhouses}

High energy consumption agricultural greenhouses can meet their energy requirements with semi-transparent photovoltaic cells covering partly their roofs as is shown in the following examples. Two cases of energy intensive greenhouses located in Crete-Greece will be examined. In the first, the greenhouse can cover its needs for lighting and operation of various electric devices with electricity and its heating and cooling needs with a high efficiency heat pump (which also consumes electricity). In the second case, the greenhouse can cover its heating requirements with solid biomass and its needs for lighting, operation of various electric devices and cooling with electricity. In the first case, the energy consumption of the abovementioned greenhouse located in Crete-Greece in an area of $1,000 \mathrm{~m}^{2}$ is presented in Table 3. 
Table 3. Energy consumption of an agricultural greenhouse using a heat pump for covering its heating and cooling requirements

\begin{tabular}{|l|l|}
\hline Surface of the greenhouse & $1000 \mathrm{~m}^{2}$ \\
\hline Electricity requirements excluding heat pump & $14000 \mathrm{KWh} /$ year \\
\hline Heating and cooling needs & $220000 \mathrm{KWh} / \mathrm{year}$ \\
\hline Total energy consumption & $234000 \mathrm{KWh} / \mathrm{year}$ \\
\hline Peak heating load & $160000 \mathrm{kcal} / \mathrm{h}$ \\
\hline Efficiency of the heat pump & $350 \%$ \\
\hline Power of the heat pump & $53.1 \mathrm{KW}$ \\
\hline Electricity consumption of the heat pump & $62857 \mathrm{KWh} /$ year \\
\hline Total electricity consumption of the greenhouse & $76857 \mathrm{KWh} /$ year \\
\hline
\end{tabular}

In the case that the semi-transparent photovoltaic cells will be placed on the roof of the greenhouse, they can cover $500 \mathrm{~m}^{2}$ of its inclined surface (less than $50 \%$ of its horizontal surface) in order to allow enough solar radiation to be transmitted inside the greenhouse. Since crystalline photovoltaic cells have higher transmittance than the corresponding thin film cells, they will be preferred. Assuming that the nominal power of the semi-transparent PVs will be $85 \mathrm{Wp} / \mathrm{m}^{2}$, it is concluded that the overall power of the modules covering partly the greenhouse will be $42.5 \mathrm{KWp}$. Taking into account that in Crete-Greece annual electricity generation from PVs is approximately $1,500 \mathrm{KWh} / \mathrm{KWp}$, the electricity generated from the photovoltaic modules in the greenhouse will be $63,750 \mathrm{KWh} / \mathrm{year}$. Therefore, the generated electricity can cover a large percentage of their annual energy requirements. Characteristics of the semi-transparent crystalline modules located on the roof of the greenhouse are presented in table 4.

Table 4. Characteristics of semi-transparent crystalline photovoltaic modules which can be placed on the roof of a greenhouse in Crete-Greece using heat pumps for heating and cooling

\begin{tabular}{|l|l|}
\hline Surface of the greenhouse & $1000 \mathrm{~m}^{2}$ \\
\hline Surface of PV modules & $500 \mathrm{~m}^{2}$ \\
\hline Power of PV modules & $42.5 \mathrm{KWp}$ \\
\hline Annual electricity generation from the PV modules & $63750 \mathrm{KWh}$ \\
\hline
\end{tabular}




\begin{tabular}{|l|c|}
\hline Annual electricity consumption of the greenhouse & $76857 \mathrm{KWh}$ \\
\hline Annual electricity consumption from the grid & $13107 \mathrm{KWh}$ \\
\hline $\begin{array}{l}\text { Percentage of total electricity consumption which is } \\
\text { covered from the electricity generated from the PV } \\
\text { modules }\end{array}$ & $82.95 \%$ \\
\hline
\end{tabular}

The proposed semi-transparent PV modules placed on the top of the greenhouse covers less than $50 \%$ of its horizontal surface and it can generate enough electricity in order to cover more than $80 \%$ of total electricity needs of the abovementioned greenhouse which uses heat pumps for its space heating and cooling. Therefore, a large part of its energy needs will be covered with solar-PV energy reducing significantly its $\mathrm{CO}_{2}$ emissions due to energy use. In the case that a higher percentage of its roof is covered with the PV modules, all its energy requirements can be met with the generated solar electricity, but in this case less solar irradiance will be transmitted inside the greenhouse. Also, in the case that the greenhouse is less energy intensive with lower energy requirements, these can be fully covered with the abovementioned semi-transparent photovoltaic modules.

In the second case where solid biomass is used for heating, the energy consumption of the greenhouse is presented in table 5 .

Table 5. Energy consumption of the greenhouse using solid biomass for heating and electricity for lighting, cooling and operation of various electric devices.

\begin{tabular}{|l|l|}
\hline Surface of the greenhouse & $1000 \mathrm{~m}^{2}$ \\
\hline Electricity requirements & $18000 \mathrm{KWh} /$ year \\
\hline Heating requirements & $216000 \mathrm{KWh} /$ year \\
\hline Total energy consumption & $234000 \mathrm{KWh} /$ year \\
\hline
\end{tabular}

Characteristics of the semi-transparent PV modules placed on the roof of the greenhouse are presented in table 6 .

Table 6. Characteristics of semi-transparent crystalline photovoltaic modules which can be placed on the roof of a greenhouse in Crete-Greece using solid biomass for heating.

\begin{tabular}{|l|l|}
\hline Surface of the greenhouse & $1000 \mathrm{~m}^{2}$ \\
\hline Surface of the PV modules & $500 \mathrm{~m}^{2}$ \\
\hline Nominal power of PV modules & $42.5 \mathrm{KWp}$ \\
\hline
\end{tabular}




\begin{tabular}{|l|l|}
\hline $\begin{array}{l}\text { Annual electricity generation from the PV } \\
\text { modules }\end{array}$ & $63750 \mathrm{KWh}$ \\
\hline $\begin{array}{l}\text { Annual electricity consumption of the } \\
\text { greenhouse }\end{array}$ & $18000 \mathrm{KWh} / \mathrm{year}$ \\
\hline $\begin{array}{l}\text { Electricity surplus which can be sold to the } \\
\text { grid }\end{array}$ & $45750 \mathrm{KWh} / \mathrm{year}$ \\
\hline $\begin{array}{l}\text { Percentage of total electricity generation } \\
\text { which can be sold to the grid }\end{array}$ & $71.76 \%$ \\
\hline
\end{tabular}

Therefore, in the case that the abovementioned energy intensive greenhouse will cover all its high heating requirements with solid biomass, the semi-transparent PV modules covering partly its roof will generate more electricity than it needs and the surplus can be sold to the grid, generating an extra income to the farmer. In this case the greenhouse will cover all its energy requirements with renewable energies, solar energy and solid biomass and it will generate also surplus electricity for the grid. Therefore, it will have negative $\mathrm{CO}_{2}$ emissions to the atmosphere due to energy use in it.

\section{Economic and environmental considerations}

Current costs of crystalline and thin film semi-transparent photovoltaics are high and the total cost of their installation including cells, inverters, cabling, controllers, labour and metal infrastructure varies between 4-5 $€$ per $\mathrm{Wp}$. Therefore, the overall cost of installing semi-transparent PV modules with nominal power $42.5 \mathrm{KWp}$ on the roof of the greenhouse will be 170,000-212,500 Euros. Due to their high investment costs, the price of solar generated electricity is higher than the price of grid electricity. Therefore, future use of semi-transparent PV cells in greenhouses needs a financial support from the governments in the framework of renewable energies promotion in agriculture. On the medium and long term their prices are expected to decrease due to higher production and technological improvements. Two other factors should be assessed for the use of semi-transparent photovoltaics in greenhouses together with the cost of generated electricity-: The first is related with reduction of the cooling loads during the summer, which results in energy saving in the greenhouse; the second is related with the reduction of $\mathrm{CO}_{2}$ emissions in the greenhouse due to energy use in it. Use of semi-transparent PV cells in greenhouses will result in the reduction of $\mathrm{CO}_{2}$ emissions due to energy use in them and, depending on the specific case; it could result in zero or negative $\mathrm{CO}_{2}$ emissions. In the two abovementioned cases the use of crystalline PV modules will result in the reduction of $63,049 \mathrm{~kg}$ of $\mathrm{CO}_{2}$ emissions provided that $1 \mathrm{KWh}$ of grid electricity corresponds to $0.989 \mathrm{~kg} \mathrm{CO}_{2}$.

\section{Conclusions}

Crystalline semi-transparent photovoltaic cells with high transmittance can be placed on the rooftops of agricultural greenhouses in a way that they will not affect the growth of the cultivated crops. Since they generate electricity, they can cover their energy requirements and the surplus can be sold to the grid. They can also contribute in energy saving since they 
reduce the cooling load during the summer. Therefore, the farmers can have an income additional to the cultivated crop decreasing also $\mathrm{CO}_{2}$ emissions due to energy use in the greenhouses. Crystalline PV cells have higher transmittance than thin films and their use is preferable on the rooftop of greenhouses. In Mediterranean region greenhouses do not require a lot of energy due to their light construction and the mild climate. However, high solar irradiance in the region allows the generation of high amounts of electricity from the PV cells. The possibility of installing semi-transparent modules in two energy intensive greenhouses located in Crete-Greece has been investigated and various estimations have been made. In the first which uses heat pumps for its heating and cooling, PV modules of a surface of $500 \mathrm{~m}^{2}$ can be placed on the rooftop of the greenhouse with an area of 1,000 $\mathrm{m}^{2}$. The nominal power of the PV modules is estimated at $42.5 \mathrm{KWp}$ and their annual generated electricity can cover more than $80 \%$ of its total energy needs. In the second greenhouse which uses solid biomass for its heating, the same PV modules can cover all its energy needs, generating a surplus which corresponds to $71.76 \%$ of its annual electricity generation and it can be sold to the grid. The overall investment cost of the crystalline PV modules is estimated at 170,000-212,500 €. Therefore, current cost of semi-transparent PVs is still high and without subsidies it is not expected to generate profits to the farmers. Further work is needed in order to estimate the rooftop area in the greenhouses which can be covered with either crystalline or thin film semi-transparent PV modules without affecting the growth of the crops and the maximum temperatures reached in the cells which adversely affects energy generation. More experimental data are also needed in order to estimate better the annual generated electricity, as well as the effect of the semi-transparent PVs in greenhouse cooling.

\section{References}

Yano, A., Onoe, M., \& Nakata, J. (2014). Prototype semi-transparent photovoltaic modules for greenhouse roof applications. Biosystems Engineering, 122, 62-73. http://dx.doi.org/10.1016/j.biosystemseng.2014.04.003

Bambara, J., \& Athienitis, A. (2015). Experimental evaluation and energy modeling of a greenhouse concept with semi-transparent photovoltaics. In 6th International Building Physics Conference, IBPC 2015. Retrieved 2015, from http://www.ibpc2015.org/app/media/uploads/files/papers/IBPC15_ID96_FinalX.pdf

Campiotti, C., Viola, C., Alonzo, G., Bibbiani, Giagnacovo, G., Scoccianti, M., \& Tumminelli, G. (2012). Sustainable greenhouse horticulture in Europe. Journal of Sustainable Energy, 3(3), 1

Carlini, M., Villarini, M., Esposto, S., \& Bernardi, M. (2010). Performance analysis of greenhouses with integrated photovoltaic modules. Lecture Notes in Computer Science, 206-214. http://dx.doi.org/10.1007/978-3-642-12165-4_17

Castellano, S. (2014). Photovoltaic greenhouses: evaluation of shading effect and its influence on agricultural performances. J Agricult Engineer, 45(4), 168.

http://dx.doi.org/10.4081/jae.2014.433

Chou, S. K., Chua, K. J., Ho, J. C., \& Ooi, C. L. (2004). On the study of an energy-efficient 
greenhouse for heating, cooling and dehumidification applications. Applied Energy, 77(4), 355-373. http://dx.doi.org/10.1016/s0306-2619(03)00157-0

Cossu M., Murgia L., Caria M., \& Pazzona A. (2010). Economic feasibility study of semitransparent photovoltaic technology integrated on greenhouse covering structures . International Conference Ragusa SHWA2010 - September 16-18, 2010 Ragusa Ibla CampusItaly "Work Safety and Risk Prevention in Agro-food and Forest Systems", p. 648-655. http://dx.doi.org/ 10.13140/2.1.1564.9921

Li, D. H. W., Lam, T. N. T., \& Cheung, K. L. (2009). Energy and cost studies of semi-transparent photovoltaic skylight. Energy Conversion and Management, 50(8), 1981-1990. http://dx.doi.org/10.1016/j.enconman.2009.04.011

Li, D. H. W., Lam, T. N. T., Chan, W. W. H., \& Mak, A. H. L. (2009). Energy and cost analysis of semi-transparent photovoltaic in office buildings. Applied Energy, 86(5), 722-729. http://dx.doi.org/10.1016/j.apenergy.2008.08.009

Marucci, A., Monarca, D., Cecchini, M., Colantoni, A., Manzo, A., \& Cappuccini, A. (2012). The semitransparent photovoltaic films for Mediterranean greenhouse: a new sustainable technology. Mathematical Problems in Engineering, 2012, 1-14. http://dx.doi.org/10.1155/2012/451934

Marucci, A., Gusman, A., Pagniello, B., \& Cappuccini, A. (2013). Limits and prospects of photovoltaic covers in Mediterranean greenhouses. J Agricult Engineer, 44(1). http://dx.doi.org/10.4081/jae.2013.e1

Marruci, A., Monarca, D., Cecchini, M., Colantoni, A., Allegrini, E., \& Capuccini, A., (2013). Use of semi-transparent photovoltaic films as shadowing systems in Mediterranean greenhouses. In Computational science and its applications - ICCSA 2013 : 13th international conference, Ho Chi Minh City, Vietnam, June 24-27, 2013 : Proceedings. Part II, 7972, 231-241. Berlin: Springer.

Ozgener, O., \& Hepbasli, A. (2007). A parametrical study on the energetic and exergetic assessment of a solar-assisted vertical ground-source heat pump system used for heating a greenhouse. Building and Environment, 42(1), 11-24.

http://dx.doi.org/10.1016/j.buildenv.2005.07.003

Park, K. E., Kang, G. H., Kim, H. I., Yu, G. J., \& Kim, J. T. (2010). Analysis of thermal and electrical performance of semi-transparent photovoltaic (PV) module. Energy, 35(6), 2681-2687. http://dx.doi.org/10.1016/j.energy.2009.07.019

Tudisca, S., Di Trapani, A. M., Sgroi, F.,Testa, R., \& Squatrito, R.,(2013). Assessment of Italian energy policy through the study of a photovoltaic investment on greenhouse. African Journal of Agricultural Research, 8(24), 3089-3096. http://dx.doi.org/10.5897/AJAR 2013.7406

Vourdoubas, J. (2015). Economic and environmental assessment of the use of renewable energies in greenhouses: a case study in Crete-Greece. Journal of agricultural science, 7(10). 
http://dx.doi.org/10.5539/jas.v7n10p48

Vourdoubas, J. (2015). Possibilities of using renewable energy sources for covering all the energy needs of agricultural greenhouses. Journal of Agricultural and Life Sciences, 2, 111-118. Retrieved 2015, from http://www.jalsnet.com/journals/Vol_2_No_1_June_2015/14.pdf

Vox, G., Scarascia-Mugnozza, G., \& Schettini, E. (2008). Renewable energy sources and greenhouse industry: trends and perspectives. In AgEng 2008 : International Conference on Agricultural Engineering: Agricultural \& Biosystems Engineering for a Sustainable World: Knossos Royal Village, Hersonissos - Crete, 23-25 June 2008, Greece.

Wong, P. W., Shimoda, Y., Nonaka, M., Inoue, M., \& Mizuno, M. (2008). Semi-transparent PV: Thermal performance, power generation, daylight modelling and energy saving potential in a residential application. Renewable Energy, 33(5), 1024-1036.

http://dx.doi.org/10.1016/j.renene.2007.06.016

Yildiz, A., Ozgener, O., \& Ozgener, L. (2011). Exergetic performance assessment of solar photovoltaic cell (PV) assisted earth to air heat exchanger (EAHE) system for solar greenhouse cooling. Energy and Buildings, 43(11), 3154-3160.

http://dx.doi.org/10.1016/j.enbuild.2011.08.013

\section{Copyright Disclaimer}

Copyright for this article is retained by the author(s), with first publication rights granted to the journal.

This is an open-access article distributed under the terms and conditions of the Creative Commons Attribution license (http://creativecommons.org/licenses/by/3.0/). 